\title{
PRIMARY CUTANEOUS LARGE B CELL LYMPHOMA OF THIGH: A CASE REPORT
}

Harindranath Harihara Ranganath1, Vinayak Chavan², Adnan Saeed ${ }^{3}$, Tejaswi Shashikant ${ }^{4}$

\section{HOW TO CITE THIS ARTICLE:}

Harindranath Harihara Ranganath, Vinayak Chavan, Adnan Saeed, Tejaswi Shashikant. "Primary Cutaneous Large B Cell Lymphoma of Thigh: A Case Report". Journal of Evolution of Medical and Dental Sciences 2015; Vol. 4, Issue 23, March 19; Page: 4037-4039, DOI: 10.14260/jemds/2015/581

ABSTRACT: We present a case of elderly male presenting with rapidly progressing swelling of left thigh, which turned out to be a primary cutaneous large B cell lymphoma, a rare and aggressive neoplastic condition with poor prognosis.

KEYWORDS: Primary cutaneous Large B cell lymphoma, thigh, aggressive, poor prognosis.

INTRODUCTION: Primary cutaneous B-cell lymphomas are a heterogeneous group of rare clonal Bcell lymphoproliferative disorders with distinct clinicopathological features compared with nodal counterparts. Primary cutaneous diffuse large B-cell lymphoma-leg type (PCLBCL-LT) is a rare subtype which constitutes only $4 \%$. They have a predilection to the leg (72\%), advanced age of onset (mean age, 76 years), high Bcl-2 expression (85\%) and frequent relapses with extracutaneous dissemination $(10-20 \%) .^{1}$

CASE REPORT: Patient a 64yr male, presented with a swelling on left thigh since 4 months which rapidly increased in size. It was associated with dull aching pain. H/o serous discharge when the swelling ruptured 10 days back. He had no history of night sweat, fever or weight loss. No h/o trauma. No h/o similar lesions elsewhere in the body. No h/o bleeding from the lesion. No h/o systemic symptoms.

There was a solitary firm large nodule measuring about $10 \times 10 \mathrm{~cm}$ with well-defined border and irregular margin present over the anterior aspect of left thigh extending from left inguinal ligament to mid-thigh region. Surface of the tumor showed ulceration and verrucous changes with serous discharge. The base was indurated. (Fig. 1, Fig. 2)

Epidermis showed ulceration with absence of epidermotropism. Dermis showed dense lymphocytic infiltration. Lymphoid cells consists of small round cells separated by thick collagen bundles with few large cells. The cells showed uniform round vesicular nucleus with scanty cytoplasm. Occasional mitosis was noted. Eosinophils and neutrophils were also seen.(Fig. 3)

IMMUNOHISTOCHEMISTRY (IHC): Neoplastic lymphoid cells were CD 20, PAX5, CD10 and Bcl2 positive and Kappa light chain restriction. CD3 positive for reactive T cells. (Fig. 4)

Diagnosis of PCLBCL-LT was done based on above findings and IHC. Patient was stared on chemotherapy.

Patient is being followed up, no complications reported yet $1 \mathrm{~m}$ after initiation. 


\section{CASE REPORT}

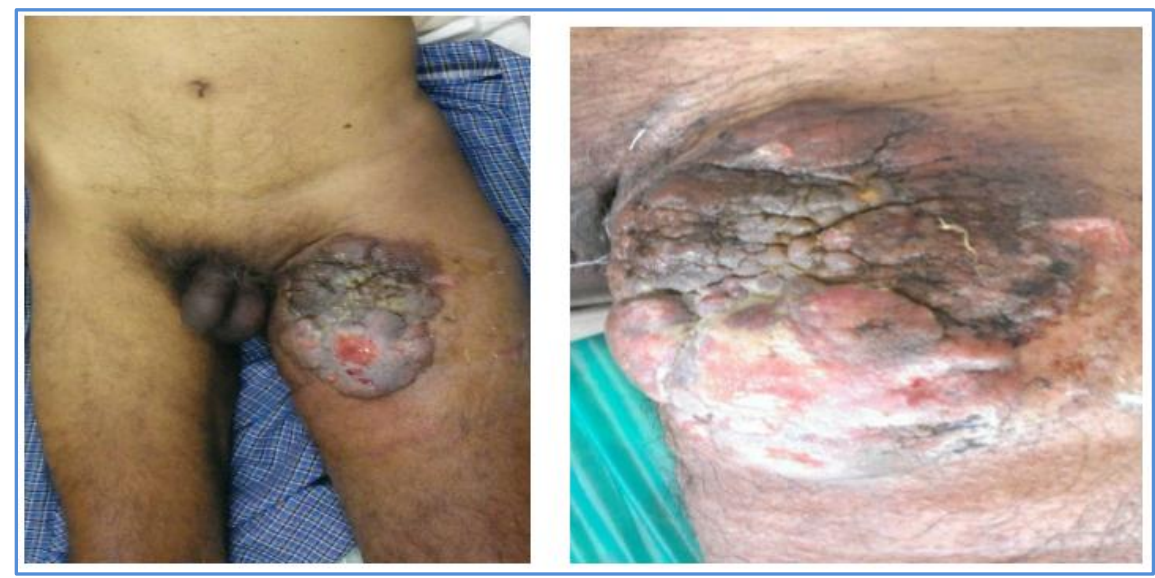

Fig. 1

Fig. 2

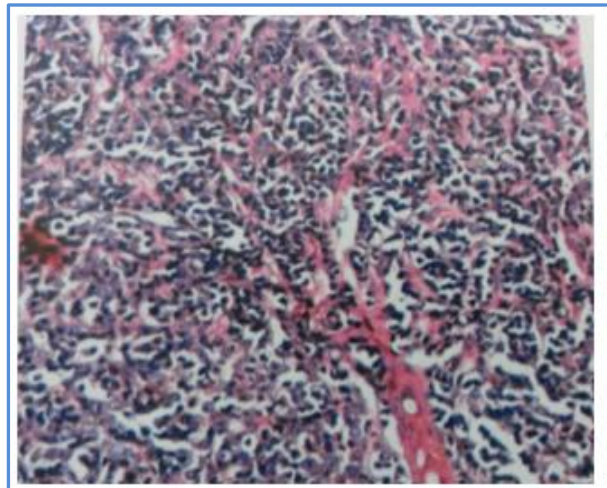

Fig. 3

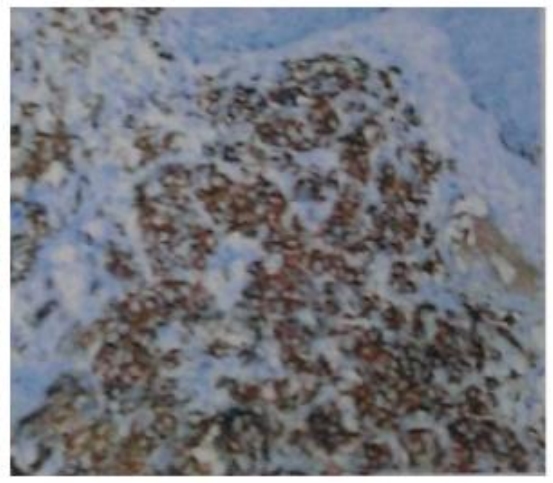

Fig. 4

DISCUSSION: Primary cutaneous diffuse large B-cell lymphoma, is a rare primary cutaneous nonhodgkin's lymphoma characterized by a diffuse proliferation of large B cells consisting of immunoblasts and centroblasts occurring mostly on legs. The current WHO-EORTC consensus classification (2005) considers two different types of PCLBCL, viz., PCLBCL, leg type, and PCLBCL others. PCLBCL usually occurs in elderly with female predominance. Though in approximately 60$70 \%$ of cases it occurs on leg, cutaneous involvement other than leg, affecting face, trunk, neck and extremities has been reported. Rarely, it may mimic chronic venous ulcer on leg. In our case, lesion appeared on left thigh.

Extracutaneous involvement after a few years of the onset of disease can occur. A case involving CNS has been reported. Histopathology is variable but the infiltrate shows no epidermotropism and there is clear grenz zone in papillary dermis. In the reticular dermis and subcutaneous fat, there is "bottom heavy" nodular or diffuse infiltrate composed of mixture of centrocytes, centroblasts and prominent reactive $\mathrm{T}$ cells. The tumor express $\mathrm{B}$-cell associated markers such as CD19, CD20, CD22 and CD79a but are CD5 negative. Most of the cases will be Bcl 2 positive. Solitary tumors can be managed by radiotherapy followed by surgery. 
For multifocal disease, chemotherapy is instituted with CHOP regimen. Rituximab (Anti CD20 antibody) either alone or in combination with CHOP (R-CHOP) has been successfully used.

CONCLUSION: PCLBCL is a rare cutaneous non-Hodgkin's lymphoma. The prognosis is poor. Multifocal disease and location over leg have got worse prognosis. Here we report this case of primary cutaneous diffuse large B cell lymphoma in a male patient because of its rarity.

\section{REFERENCES:}

1. Hristov AC. Primary cutaneous diffuse large B-cell lymphoma, leg type: Diagnostic considerations. Arch Pathol Lab Med 2012; 136: 876-81.

2. Shaikh AJ, Masood N, Ahsan A, Memon W. Primary cutaneous B cell lymphoma - Leg type (NEW EORTC - WHO classification), with nasal sinuses involvement. J Pak Med Assoc 2008; 58: 274-6.

3. Kumar YS, Girisha BS, Shetty KJ, Kishan Prasad HL, Impana BD, Dasgupta A. Rare case of primary cutaneous diffuse large B-cell lymphoma-leg type with testicular infiltration. J Can Res Ther [Epub ahead of print] [cited 2014 Dec 10].

4. Willemze R, Jaffe ES, Burg G, Cerroni L, Berti E, Swerdlow SH, et al. WHO-EORTC classification for cutaneous lymphomas. Blood 2005; 105: 3768-85.

5. Whittaker SJ. Cutaneous Lymphoma and Lymphocytic infiltrates. In: Burns T, Breathnach S, Cox N, Griffiths C, editors. Rook's textbook of Dermatology. 8th ed. UK, Wiley Blackwel publications; 2010. P. 57.47-57.49.

6. Belousova IE, Vanecek T, Skreg SV, Rodionov AN, Samtsov AV, Kazakov DV. Unusual clinicopathological presentation of primary cutaneous diffuse large B-cell lymphoma, leg type, with multiple nodules and widespread garland-like lesions. Am J Dermatopathol 2009; 31: $370-4$.

\section{AUTHORS:}

1. Harindranath Harihara Ranganath

2. Vinayak Chavan

3. Adnan Saeed

4. Tejaswi Shashikant

\section{PARTICULARS OF CONTRIBUTORS:}

1. Associate Professor, Department of General Surgery, Bangalore Medical College \& Research Institute, Bangalore.

2. Post Graduate, Department of General Surgery, Bangalore Medical College \& Research Institute, Bangalore.

FINANCIAL OR OTHER COMPETING INTERESTS: None
3. Senior Resident, Department of General Surgery, Bangalore Medical College \& Research Institute, Bangalore.

4. Post Graduate, Department of General Surgery, Bangalore Medical College \& Research Institute, Bangalore.

\section{NAME ADDRESS EMAIL ID OF THE CORRESPONDING AUTHOR:}

Dr. Harindranath Harihara Ranganath, \# 1852, ${ }^{\text {st }}$ Cross, Prakash Nagar, Bangalore-560021.

E-mail: harindranath82@gmail.com

Date of Submission: 20/02/2015.

Date of Peer Review: 21/02/2015.

Date of Acceptance: 07/03/2015.

Date of Publishing: 18/03/2015. 